\title{
LEITE DERRAMADO E SEU PROCEDIMENTO PROBLEMATIZADOR
}

\author{
Marli Teresinha da Silva* \\ Juracy Assmann Saraiva*
}

RESUMO: A literatura pós-moderna é problematizadora, na medida em que se contrapõe a conceitos preconcebidos. Este artigo centra-se na problematização do racismo e do sexismo, presentes na sociedade brasileira, e que são evidenciadas em Leite derramado, de Chico Buarque, por meio do procedimento artístico, em que o narrador entrelaça o passado e o presente. Para tanto, fundamenta-se em estudos da narratologia, particularmente nos que enfocam o leitor implícito, a intertextualidade e a metaficção.

PALAVRAS-CHAVE: Leite derramado; Procedimento Narrativo; Racismo; Sexismo.

\section{Introdução}

Em suas memórias, Eulálio, protagonista de Leite derramado, de Chico Buarque descreve fatos de sua vida pessoal, que funcionam como memória coletiva da sociedade brasileira, relativa ao período em que a história ficcional se situa. A partir da maneira como são narrados, esses fatos não ficam isolados no passado, pois desafiam o conhecimento histórico e literário do leitor, condicionando-o a problematizar questões sociais e

${ }^{*}$ Mestre em Letras pela Universidade Feevale.

** Professora da Universidade Feevale. Doutora em Teoria Literária pela Pontifícia Universidade Católica do Rio Grande do Sul (Puc-RS), com estágio de Pós-Doutorado em Teoria Literária pela Universidade Estadual de Campinas (Unicamp). Bolsista de Produtividade do CNPq. 
políticas por meio da subjetividade daquele que narra. Entretanto, a desintegração psíquica do protagonista de Leite derramado reflete um paradoxo - ao mesmo tempo que usa referências históricas para organizar e dar sentido ao passado, ele se afasta do mundo real.

O vai e vem das memórias de Eulálio, as repetições de eventos e as transições temporais desordenadas - que diferenciam o protagonista do narrador - constituem um discurso caótico, sem compromisso com a história factual, mas que a reescreve, porque a tem enredada em si mesmo. Assim, o procedimento artístico de Leite derramado, ao passo que aproxima o leitor dos fatos históricos, por meio da verossimilhança, afasta-o devido às configurações do discurso.

A narrativa de Leite derramado remonta, por meio das memórias de seu narrador, à sociedade escravagista e patriarcal do Império, ao sistema capitalista da República, para situar-se na contemporaneidade. Conforme informado na orelha do próprio livro, "Um homem muito velho está num leito de hospital. Membro de uma tradicional família brasileira, ele desfia, num monólogo dirigido à filha, às enfermeiras e a quem quiser ouvir, a história de sua linhagem desde os ancestrais portugueses, passando por um barão do Império, um senador da Primeira República, até o tataraneto, garotão do Rio de Janeiro atual".

Assim, nos liames da ficção e da história, este romance memorialístico faz com que circunstâncias do passado, como a escravidão e a repressão à liberdade feminina, sejam articulados com seus vestígios no presente, expressos no preconceito de cor e no sexismo.

\section{Entrelaçamento entre o passado e o presente}

A ideia de articulação, entre o passado e o presente, já está no próprio nome do narrador autodiegético, Eulálio, cujo significado remete àquele que sabe articular bem as palavras. Com efeito, a saga familiar descrita tem como característica o bom uso da palavra, recurso que, entre outros resultados, indica de quem é a voz que fala. Em sua poiesis, o autor de Leite derramado vale-se do cuidado com a elaboração do material verbal para 
distinguir o narrador de outras personagens, peculiaridade linguística que pode ser vista nas passagens em que Eulálio se dirige à filha ou à enfermeira, como no excerto que segue:

[...] Veja só, neste momento olho para você, que toda noite está comigo tão amorosa, e fico até sem graça de perguntar seu nome de novo. [...] Eu por mim sonhava com você em todas as cores, mas meus sonhos são que nem cinema mudo, e os atores já morreram há tempos. Dia desses fui buscar meus pais no parque dos brinquedos, porque no sonho eles eram meus filhos. (BUARQUE, 2009, p. 14-15)

Por meio do uso do verbo no presente e do dêitico 'neste', o leitor é capaz de identificar que a voz que fala é a do protagonista, bem como, mediante o uso do verbo no passado e do dêitico 'desses', o leitor identifica a remissão dele ao tempo pretérito. Nesse jogo de lá e cá, o narrador autodiegético ${ }^{1}$ entrelaça o passado e o presente.

Entretanto, ao proferir palavras bem alinhavadas, Eulálio apresenta, no âmbito de famílias patriarcais, mulheres sem voz, que têm seus desejos, sua força e sua capacidade subjugados. A repressão à liberdade feminina é revelada desde o primeiro capítulo, quando Eulálio se dirige à enfermeira e diz que irão se casar quando ele sair do hospital. Em seu discurso, o protagonista destaca: "Na fazenda você tratará de mim e de mais ninguém, de maneira que ficarei completamente bom” (BUARQUE, 2009, p. 6). Marcado por uma fala autoritária, mediante o uso do verbo no futuro do indicativo, o discurso revela que Eulálio é um sujeito que não cogita respeitar a vontade feminina.

No entanto, a linguagem utilizada vai além da exposição do autoritarismo do protagonista, pois revela a presença do leitor implícito, que permeia o texto e assume o papel de receptor, isto é, guia o leitor real a desvendar as referências internas e externas, que

${ }^{1} \mathrm{O}$ termo autodiegético remete ao narrador que conta sua própria história, na condição de protagonista. 
trazem coerência e verossimilhança ao monólogo. Assim, o leitor implícito serve de modelo ao leitor empírico e "define um ponto de vista que permite ao leitor real compor o sentido do texto" (COMPAGNON, 2010, p. 149). A exemplo disso, o enunciado de Eulálio, "Quando eu sair daqui, vamos nos casar na fazenda da minha infância feliz" (BUARQUE, 2009, p. 5) obriga o leitor empírico a preencher os espaços deixados pelo protagonista, na medida em que a construção textual não identifica quem é o interlocutor do verbo conjugado na primeira pessoa do plural. À não identificação desse sujeito alia-se a não identificação da fazenda referida pelo protagonista, impondo, assim, ao leitor real a busca de informações a fim de completar o texto.

O caminho percorrido em busca de respostas às lacunas do texto é conduzido por uma linguagem concisa e provocativa, o que contribui para a fruição da leitura e para a convergência do repertório ${ }^{2}$ do leitor real. Devido a isso, as provocações que emergem da narração deslocam a curiosidade do leitor para Matilde, personagem coadjuvante que se torna o centro da narrativa.

A diegese de Eulálio é permeada por divagações sobre o destino da "mais moreninha das congregadas marianas" (BUARQUE, 2009, p. 20), que desaparece na história, mas sem, antes, deixar de ser vítima do preconceito que jorrava em sua direção. "Só porque Matilde era de pele quase castanha” (BUARQUE, 2009, p. 20), experimentou a antipatia da sogra, rejeição que fica exposta por intermédio do narrador:

[...] Nisso não puxei ao meu pai [...]. Nem à minha mãe, que ao me ver arrastando a asa para a Matilde, de saída me perguntou se por acaso a menina não tinha cheiro de corpo. (BUARQUE, 2009, p. 20)

[...] mas com a mão pesada, ela tocou um batuque [...] E mamãe se despencou pela escada, para ver que diabo se passava. (BUARQUE, 2009 , p. 45)

${ }^{2}$ Expressão usada por Wolfgang Iser e que equivale ao Horizonte de Expectativas, de Hans Robert Jauss. 
As marcas do preconceito, sentidas pela moça, são desenhadas pela sogra, mas, em especial, por seu marido. Todavia, não é a cor da esposa que o desagrada, pelo contrário, esta característica faz com que ele se sinta atraído por ela. São a sua ousadia e beleza que despertam o ciúme e a prepotência dele. Em vista disso, por vezes, a moça busca refúgio na cozinha da casa.

Volta e meia levava a criança à cozinha, dava conversa às empregadas, era vezeira em almoçar ali com a babá. (BUARQUE, 2009, p. 66)

Os indícios de que a negritude e a personalidade de Matilde desvelam o caráter opressor de Eulálio aparecem na passagem em que ele desiste de levar a esposa até o cais, para recepcionar um engenheiro francês.

E quando lhe anunciei que iriamos em breve ao cais do porto, para receber o engenheiro francês, ela [...] cortou os cabelos à la garçonne. Chegado o dia, vestiu-se como achou que era de bom-tom, com um vestido de cetim cor de laranja e um turbante de feltro mais alaranjado ainda. [...] Nem parei para pensar de onde vinha a minha raiva repentina, só senti que era alaranjada a raiva cega que tive da alegria dela. (BUARQUE, 2009, p. 12)

A cada passagem como essa, o narrador vai dosando detalhes do cotidiano do casal e das características individuais de cada um. Como visto, o excerto mostra que Matilde se posiciona na vanguarda, pois seu corte de cabelo é característico de mulheres que viraram símbolo da moda nos anos de 1920. A cor vibrante do vestido demonstra sua vaidade e força interior. Acrescenta-se a isso, o fato de a cor laranja ser uma cor quente, servindo de referência à sensualidade e à alegria de Matilde. Entretanto, se, por um lado, seu jeito de ser e de vestir revelam sua ousadia, contemporaneidade e valoração da cultura que lhe é própria - como o turbante, as roupas chamativas pelas cores e pelo corte, o batuque tocado no piano, o maxixe dançado com o francês etc. -, por outro, colaboram para estabelecer sua desarmonia em relação ao padrão considerado adequado para moças de famílias distintas, provocando, assim, além de ciúmes, a vergonha no marido. 
Acerca da sensualidade da personagem, enfatizada em várias passagens da narrativa, percebe-se que as inferências que dela decorrem sofrem mutações. Na medida em que o narrador avança em seu relato, o ciúme e a confusão mental também avançam, e isso traz novas significações à característica sedutora de Matilde, sem, contudo, significar, que o comportamento da personagem tenha mudado. O que se altera é a forma como ela é vista pelo marido. Assim, no início da relação amorosa dos dois, a sensualidade da esposa era envolvente, e, no decorrer da história, ela toma ares de traição.

[...] tudo era pretexto para ele contemplar os seios redondos de Matilde, que amamentava sem cerimônia no meio da sala. (BUARQUE, 2009, p. 158)

Contudo, apesar da erotização do mamilo cheio de leite, ele é, acima de tudo, o símbolo da vida e do afeto, que foi negado a Eulálio:

[...] Pudera, sou filho único, mamãe não dava colo senão a mim, e mesmo assim só de quando em quando. Se eu começasse a fazer manha, ela me passava para a governanta, que me passava para a babá, que me passava para a ama-de-leite me aleitar. (BUARQUE, 2009, p. 194)

O afeto que Eulálio não recebera da mãe, era garantido pela ama-de-leite. Entretanto, o afeto e o alimento concedidos pela negra lactante ao filho do patrão não lhe garantem maior respeito da parte deles, tampouco de Eulálio. Em nenhum outro momento da narrativa, ele menciona sua ama-de-leite ou dá a ela um tratamento diferenciado daquele dado aos negros que aparecem na narrativa. Esse é caso de Balbino, amigo de infância do narrador, que fora sempre tratado como escravo, mostrando que "a relação senhor versus escravo é naturalmente demarcada pelo domínio do Outro, o que, em si, constitui um ato violento” (KUNZ \& CONTE, 2015, p. 275). Portanto, Eulálio sente-se no direito de reificar o "amigo":

Durante um período, para você ter uma ideia, encasquetei que precisava enrabar o Balbino. (BUARQUE, 2009, p. 19) 
Com esse enunciado, Eulálio inicia o relato de alguém que busca satisfação na submissão do outro, para escravizá-lo a seus caprichos. O prazer em ver Balbino catar mangas no alto da árvore, arriscando a vida, era tamanho que Eulálio se vê atraído sexualmente pelo amigo. Desse modo, o sentido do verbo “enrabar" é ambivalente, pois não só denota o ato sexual, mas também o ato de escarnecer, maltratar.

No entanto, essa passagem do texto também figura como um exemplo do diálogo que os textos estabelecem entre si, bem como do quanto a narrativa apela para o conhecimento literário do leitor, mostrando, dessa forma, que a intertextualidade é a memória que a literatura tem de si mesma (SAMOYAULT, 2008). A perversão de Eulálio, que faz de Balbino um joguete, remete à crueldade exercida pelo menino Brás Cubas.

[...] eu tinha apenas seis anos. Prudêncio, um moleque de casa, era o meu cavalo de todos os dias; punha as mãos no chão, recebia um cordel nos queixos, à guisa de freio, eu trepava-lhe o dorso, com uma varinha na mão, fustigava-o, dava mil voltas a um e outro lado, e ele obedecia, - algumas vezes gemendo, - mas obedecia sem dizer palavra, ou, quando muito, um - "ai, nhonhô!" - ao que eu retorquia: - "Cala a boca, besta!" (ASSIS, 1980, p. 41)

As maldades de Brás Cubas e de Eulálio dialogam entre si e são demonstrações do comportamento opressor da sociedade brasileira, que perpassa períodos históricos, concedendo ao texto um caráter de memória coletiva.

Freyre (2005, apud KUNZ; CONTE, 2015, 275) afirma que “O processo escravagista 'desenraizou o negro do seu meio social e de família, soltando-o entre gente estranha e muitas vezes hostil"'. A assertiva de Freyre é presentificada na narrativa, mediante passagens em que a origem de Matilde é mencionada. Quando apresentado à neta Eulália, doutor Vidal, pai de Matilde, se faz de desentendido e profere: “Ah, sim, Matilde, uma escurinha que criamos como se fosse da família, [...]” (BUARQUE, 2009, p. 192). O posicionamento do Dr. Vidal confirma a pista dada pela mãe da moça, em uma conversa com D. Maria Violeta (mãe de Eulálio), de que Matilde fora retirada de seu lar de origem. 
E um dia a gorda mãe de Matilde deixou escapar que a menina não era filha sua, mas fruto de uma aventura do deputado, lá para as bandas da Bahia. (BUARQUE, 2009, p. 73)

Como visto, os sujeitos de cor representados em Leite derramado são vítimas das ações e concepções sociais que colocam o negro à margem, desprezados não somente por sua cor, mas pela origem e tudo o que possa vir dela, como sua cultura, valores, desejos, capacidades intelectuais e braçais. Balbino, por exemplo, escravo fiel aos afazeres braçais, ordenados por seu patrão, carrega já no nome o peso da desigualdade, na medida em que Balbino vem do Latim, balbus, aquele que gagueja, o que o opõe a Eulálio, aquele que fala bem.

Com efeito, Balbino tem, no decorrer da trama, seus valores, desejos e capacidades intelectuais e braçais desvalorizados, bem como Matilde e sua prole. A filha Eulália ganha algum sinal de valoração por parte da avó paterna quando perde os traços que a assemelham à mãe. Tal inferência está expressa no relato feito por Eulálio à própria filha.

[...] Até minha mãe, que não era de lhe dar muita atenção, se impressionou de ver como você se transfigurava. A menina está mesmo enfeitando, disse mamãe com vaidade distraída, pois você mais e mais se assemelhava a ela própria. (BUARQUE, 2009, p. 94-95)

O excerto mostra que o preconceito persiste sobre as novas gerações. Contudo, não bastasse o preconceito de cor, a vida de Eulália também é marcada pelo abandono, pela desestruturação da família e por sua desvalorização enquanto sujeito e mulher. A começar pela avó, que a presenteou com roupas de menino, depois pela perda da mãe, pela negligência do pai, pela discriminação vivenciada na escola, pela desilusão amorosa, pela perda de seus bens materiais, pela ausência de vestígios materiais de sua existência, a não ser pelo filho, que também perdeu. Eulália tem uma vida apagada, configurando-se na representação da mulher coisificada, isto é, aquela que não tem identidade. Para o ex-marido e para a amiga artista, ela foi um banco monetário; para o pai, símbolo da decadência, por um lado, e elo entre passado e presente, por outro. 
À margem de uma vida social e do mercado de trabalho, Eulália não produz nem tem capital, pelo contrário, seu pai a tem como culpada pela extinção dos bens da família.

[...] aí é mesmo que Maria Eulália vai me entregar às baratas. Isso porque ela não sabe que ainda tenho recursos, se soubesse já os teria torrado como torrou o casarão, o chalé, os imóveis todos, até o jazigo da família ela passou nos cobres. (BUARQUE, 2009, p. 120)

Aos olhos do pai, a filha é alguém sem habilidades para finanças ou para constituir família, tampouco é dotada de beleza ou de aptidões domésticas. Desse modo, Eulália é a negação daquilo que seu pai valoriza: ostentação e poder. Contudo, apesar da vida infeliz, Eulália, entre todos os parentes, é a única que não o abandona. Talvez porque ela saiba que os "defeitos" que o pai vê nela, são também os seus: Eulálio não deu certo para a vida política, nunca trabalhou, não formou amizades, seu casamento acabou e o dinheiro de que usufruiu foi herdado.

O tratamento dado à filha e as concepções de Eulálio expostas pelos relatos demostram seu caráter sexista. Tal característica não se dissipa com o tempo, tendo seus vestígios denunciados pelo tratamento dado à enfermeira. Desde o início da narrativa, Eulálio mostra ser alguém que discrimina o sexo oposto, tanto ao que tange à sua sensibilidade, quanto à sua capacidade intelectual.

[...] Eu cogitaria mesmo em levá-la à recepção da embaixada, [...]. Mas concluí que não valia a pena, Matilde ficaria encabulada naquele meio. Política não lhe interessava, negócios, muito menos, amava fitas de caubói, mas não sustentaria uma conversação sobre literatura. (BUARQUE, 2009, p. 44-45)

A partir do excerto é possível constatar que os valores de Eulálio são semelhantes aos que vigoram na elite social e são vigentes desde sua infância. Entretanto, as transformações sociais, culturais e familiares que ele acompanha até chegar à velhice não apagam ou modificam seu modo de ver as pessoas e o mundo. 
Emenda-se a isso, o fato de as pessoas, os lugares e os costumes do passado estarem mais vivos em sua memória do que os do presente. Sob esse ângulo, Eulálio é repositório da cultura brasileira e suas memórias tornam-se textos sociais, na medida em que:

Não podemos conhecer o passado, a não ser por meio de seus textos: seus documentos, suas evidências, até seus relatos de testemunhas oculares são textos. (HUTCHEON, 1991, p. 34)

Consideradas como texto, as memórias de Eulálio passam por um caminho circular, isto é, voltam ao seu ponto de partida. No que tange ao tempo e ao espaço, a narrativa inicia e termina no leito de um hospital, no tempo presente. No que tange aos valores do protagonista, estes também permanecem os mesmos, o que se percebe a partir das conversas de Eulálio com a enfermeira e das menções à Matilde. Para Eulálio, tanto no passado quanto no presente, a mulher deve submeter-se à vontade do marido.

A estrutura circular de Leite derramado interliga o passado individual de Eulálio com o passado coletivo da sociedade brasileira. Nesse processo de produção textual, o autor do romance concede à diegese um caráter de metaficção historiográfica. Isto é, Leite derramado é um romance contemporâneo que estabelece uma relação com o passado, entretanto esta relação não está somente nas referências históricas, mas na forma de narrar. Incorporar a história social e política em um romance demanda uma "intensa autoconsciência" em relação à maneira de narrar o passado (HUTCHEON, 1991, p. 150). Com efeito, a dicotomia entre texto histórico e texto ficcional dá lugar ao romance pós-moderno, que é composto pelo entrelaçamento do material histórico e do discurso ficcional. Desse modo, ao unir eventos históricos ao discurso poético, que tem como característica incitar reflexões críticas, Leite derramado problematiza conceitos pré-concebidos. 


\section{Sexismo e racismo como herança familiar}

$\mathrm{Na}$ voz de Eulálio, as mulheres estão mais para fêmeas, submissas aos caprichos dos homens, do que para sujeitos com competências e habilidades reconhecidas. Posicionamento que fica evidente em referências ou nos monólogos em que uma personagem feminina é o foco, como na passagem em que ele se dirige à suposta redatora de suas memórias:

Antes de exibir a alguém o que lhe dito, você me faça o favor de submeter o texto a um gramático, para que seus erros de ortografia não me sejam imputados (BUARQUE, 2014, p. 18).

Com efeito, o narrador- protagonista enfatiza o âmbito profissional, e as mulheres que ele cita atuam em profissões subalternas e, frequentemente, em situações de subserviência aos homens. Entre as profissões mencionadas na narrativa encontram-se as seguintes: taquígrafa, enfermeira, arrumadeira, professora, empregada doméstica, lavadeira, dançarina(TV), cantora, secretária, assessora e atendente de butique. Mesmo que o ofício não exponha, em sua origem, o servilismo ao sexo oposto, ele é avaliado negativamente.

O rebaixamento das mulheres revela-se até mesmo na explicitação da sexualidade de Eulálio, que vê as mulheres como "fêmeas":

Olhando meu corpo, tive a sensação de possuir um desejo potencial equivalente ao dele, por todas as fêmeas do mundo, porém concentrado numa só mulher. (BUARQUE, 2014, p. 33)

O excerto exemplifica a reação de Eulálio, horas depois de ter conhecido Matilde, e compõe uma passagem em que o narrador compara a sua libido com a de seu pai. De certa forma, a árvore genealógica de Eulálio aponta para o sexismo e o racismo recorrentes na família e que se presentificam na narrativa, que promove o apagamento das mulheres, cuja voz somente aparece por meio da voz do narrador autodiegético.

Sob o ângulo da genealogia, as mulheres aparecem somente a partir da avó, cujo nome não é mencionado e cuja existência é referenciada para explicar o reconhecimento de Eulálio, diante da enfermeira, de que fora excessivamente ciumento com Matilde. Ele 
refere o comportamento opressor e adúltero do avô, acrescentando que, diante desse, a avó transformara seu ciúme em reumatismo, levando um sentimento gentil a transformarse em algo mórbido:

Com o tempo aprendi que o ciúme é um sentimento para proclamar de peito aberto, no instante mesmo de sua origem. Porque ao nascer, ele é realmente um sentimento cortês, deve ser logo oferecido à mulher como uma rosa. Senão, no instante seguinte ele se fecha em repolho, e dentro dele todo mal fermenta. (BUARQUE, 2014, p. 6162).

Contudo, mais adiante, ele narra que, frente às reclamações da esposa, o avô a enclausura num chalé à beira mar, "para que mitigasse seu sofrimento com banhos terapêuticos” (BUARQUE, 2014, p. 62). A partir desse silenciamento da voz da avó, em virtude de sua reação a cada vez que o marido "ia procurar as negras", vício que mantinha "desde fedelho" (BUARQUE, 2014, P. 62), o leitor entende que a mulher é subjugada pelo marido e o quanto o é por Eulálio, cuja narração é incapaz de traduzir a dor feminina em face da traição e do abandono.

Sob esse ângulo, poder-se-ia dizer que D. Maria Violeta, mãe de Eulálio, se sobressai, na medida em que lhe são transferidas qualidades positivas: ser boa pianista, falar bem o francês e conservar uma fala clara e correta, apesar da idade avançada. No entanto, as qualidades de D. Maria Violeta não produzem a energia necessária para se libertar de um marido que a trai e, sabendo das orgias do marido, ela desiste de viajar com ele para fazer compras na Europa e contenta-se em "lhe fazer as encomendas" (BUARQUE, 2014, p. 83); aceita os recados da assessora, quando esta avisa que o senador amanhecerá no trabalho, embora desconte sua mágoa nos empregados; passa anos de luto, fingindo não saber que o marido fora assassinado por um cônjuge "corno". Por fim, quando experimenta um relacionamento baseado no respeito mútuo, com seu fiel chofer Auguste, ela perde a habilidade da fala, o que dá sequência à tradição familiar do silenciamento feminino. 
Ainda, no que tange às mulheres que compõem a genealogia, tem-se Eulália, que deveria herdar, graças ao nome, a habilidade comunicativa da família, ou melhor, dos homens da família, já que seu nome é a versão feminina de Eulálio, seu pai. Mas, a busca pelas referências à Eulália na narrativa mostra o oposto. As menções à filha são permeadas de expressões que a desvalorizam, como "torta" e "destrambelhada" (p. 18), que fala "disparates” (p. 78), "poderia tentar a psicanálise” e “está gagá” (BUARQUE, 2014, p. 192), entre outras. Fadada ao desprezo por parte de seu pai, sujeita-se aos desaforos advindos dele e, a exemplo de sua bisavó, fecha-se, já não em doenças, mas na religião.

O ponto de vista que desprestigia as mulheres e, entre essas, as que trazem a marca do preconceito nas menções à cor da pele, recai sobre Matilde, o que pode ser ilustrado por enunciados retirados do texto, conforme demonstra o quadro 1:

Página

\begin{tabular}{l|l}
\hline Suava bastante & 05 \\
\hline Cor castanha & 20 \\
\hline Mais moreninha das congregadas marianas & 20 \\
\hline Pele quase castanha & 29 \\
\hline Em francês era quase tatibitate & 44 \\
\hline Política não lhe interessava, negócios, muitos menos, amava fitas de caubói, & 45 \\
mas não sustentaria uma conversação sobre literatura & \\
\hline Pouco sabia de ciências, geografia e história & 45 \\
\hline Era mulher de dançar maxixe, e não de beijar a mão & 66 \\
\hline O sol estampado em sua pele & 86 \\
\hline Desarvorada & 95 \\
\hline Era a mais moreninha da classe & 96 \\
\hline
\end{tabular}

Quadro 1: preconceito despejado em Matilde Fonte: as autoras do artigo

Os enunciados listados enfatizam a cor da pele de Matilde, como algo negativo, e a escassez de conhecimento dela. Por não ser branca e por sua falta de erudição, Matilde não preenche os requisitos para fazer parte da distinta e tradicional família Assumpção. Ciente 
disso, a personagem não se afasta do grupo a que se vincula e compartilha com eles os dissabores de sua vida de casada. Como exemplo das escolhas de Matilde, tem-se a ocasião em que falta luz durante um jantar na casa da sogra, quando ela partilha "uma bandeja de pâtisserie ao pé do fogão", "sentada no chão com o velho Auguste”, ecoando risadas até a volta da eletricidade (BUARQUE, 2014, p. 90). Ao juntar-se aos "seus" na cozinha, ao optar pelo maxixe, ao usar roupas consideradas escandalosas, Matilde afirma sua identidade e indicia práticas preconceituosas, enraizadas na tradição familiar.

\section{Considerações finais}

Como texto, as memórias de Eulálio passam por um caminho circular, pois retornam ao ponto de partida. As idas e vindas de suas lembranças, mesmo que desordenadas, são um exercício de reflexão sobre sua existência, e o olhar para o passado leva-o a entender o presente. Entretanto, os devaneios e as repetições de Eulálio conjugam a imaginação com dados de realidade. Dessa maneira, a linguagem poética, que tem fatos históricos como pano de fundo, estabelece com o leitor um jogo de percepção e de reflexão, pois este, primeiramente percebe o ocorrido pelo olhar de Eulálio para, em seguida, fazer suas próprias deduções, ao interligar aquilo que leu com aquilo que conhece previamente. Assim, no lá e cá de Eulálio, questões sociais e políticas são problematizadas e pedem a participação do leitor.

Com efeito, o procedimento artístico de Leite derramado faz com que o ato de ler não seja um momento de percepção e aceitação natural do passado, mas, sim, de problematização, de comparação do preconceito em relação à mulher e do racismo vigente no período em que a história ficcional se situa com a situação no presente. O leitor estabelece uma relação entre o universo ficcional e a realidade, perfazendo, também ele, um caminho circular, que o leva do texto à realidade, problematizando-a, assim como Chico Buarque faz em seu processo criativo. 


\section{LEITE DERRAMADO AND THE PROBLEMATIZATION THAT EMERGES FROM THE NARRATIVE PROCEDURE}

ABSTRACT: The post-modern literature has a defamiliarization character, insofar as it contrasts with preconceived concepts. This article is centred on racism and sexism problematization, both current in Brazilian society, which are evidenciated in Leite derramado, by Chico Buarque, through the artistic procedure, in which the narrator interconnects the past and present. For this, it is based on studies of narratology, particularly those that focus on the implicit reader, intertextuality and metafiction.

KEYWORDS: Leite derramado; Narrative procedure; Racism; Sexism.

\section{REFERÊNCIAS}

ASSIS, Machado de. Memórias Póstumas de Brás Cubas. São Paulo: Egéria LTDA, 1980, p. 41.

COMPAGNON, Antoine. O demônio da teoria: literatura e sendo comum. Belo Horizonte: UFMG, 2010.

HUTCHEON, Linda. Poética do pós-modernismo: história, teoria, ficção. Rio de Janeiro: Imago, 1991.

KUNZ, Marinês A.; CONTE, Daniel. A figuração do negro na literatura infantil e juvenil veiculada no Brasil. Madrid: Revista de Estudos Literários UCM, 2015.

SAMOYAULT, Tiphaine. A intertextualidade. São Paulo: Hucitec, 2008.

SARAIVA, Juracy Assmann. "Dinâmica da memória: Leite derramado e Memórias Póstumas de Brás Cubas." Machado de Assis em Linha, v. 21, 2017.Disponível em: $<$ http://submission.scielo.br/index.php/mael/article/view/174996>. Acesso em: 26 mar. 2018.

Recebido em: 21/04/2018. Aprovado em: 03/05/2018. 